\title{
City of South Lake Tahoe Subdivision Ordinance: \\ An Opportunity for Smart Growth, Sustainability and Application Streamlining
}

\author{
A Professional Project \\ presented to \\ the Faculty of California Polytechnic State University, \\ San Luis Obispo \\ In Partial Fulfillment \\ of the Requirements for the Degree \\ Master of City and Regional Planning in the \\ College of Architecture and Environmental Design \\ Hilary Kay Hodges
}

April, 2009 
South Lake Tahoe Subdivision Ordinance ii

(C) 2009

Hilary Kay Hodges

ALL RIGHTS RESERVED 


\section{COMMITTEE MEMBERSHIP}

TITLE:

AUTHOR:

DATE SUBMITTED:

COMMITTEE CHAIR:

COMMITTEE MEMBER:

COMMITTEE MEMBER:
City of South Lake Tahoe Subdivision Ordinance: An Opportunity for Smart Growth, Sustainability and Application Streamlining

Hilary Kay Hodges

April, 2009

Paul Wack, Professor

Teri Jamin, City of South Lake Tahoe Community Development Director

Kelly Main, Assistant Professor 


\begin{abstract}
City of South Lake Tahoe Subdivision Ordinance: An Opportunity for Smart
\end{abstract} Growth, Sustainability and Application Streamlining

$$
\text { Hilary Kay Hodges }
$$

The City of South Lake Tahoe currently does not have an adopted subdivision ordinance. This has caused confusion about the approval process and regulatory requirements as well as delays in application processing. This Professional Project will explore the opportunity for the City to adopt a subdivision ordinance that would provide direction for subdivision design and approval and further the City's smart growth and sustainability policies. However, there would need to be careful consideration for the potential increase in costs that are associated with additional fees or off-site improvement requirements. The Subdivision Ordinance would be written with the goals of achieving a streamlined process and incorporating design standards consistent with smart growth principles and sustainability consistent with the City's Sustainability Plan. In addition, the Subdivision Ordinance must be consistent with the goals, policies, and programs of the City of South Lake Tahoe General Plan.

The project would begin with a literature review on subdivision regulation and the regulatory environment in South Lake Tahoe. Several subdivision ordinances would be reviewed for their ability to meet the goals of the South Lake Tahoe Ordinance. Throughout the process there will be consultation with other professionals. The final product will be a draft subdivision ordinance and an analysis of how well the draft achieves the goals. 


\section{TABLE OF CONTENTS}

CHAPTER

I. INTRODUCTION ............................................... 1

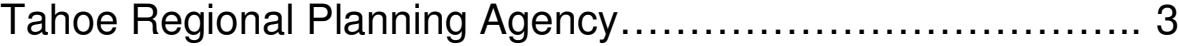

Purpose of the Subdivision Ordinance........................... 7

Issues and Opportunities..................................... 13

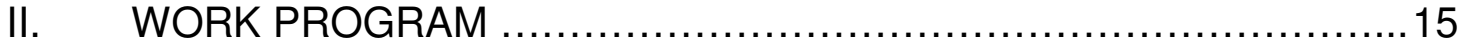

Work Program Outline ......................................... 15

Review of Ordinances from Other Jurisdictions................. 16

III. DRAFT CITY OF SOUTH LAKE TAHOE SUBIDVISION

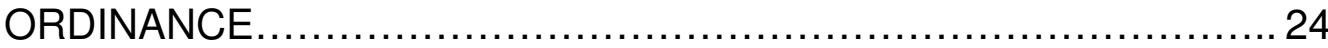

Form and Content.............................................. 24

Evaluation of Draft Ordinance.................................25

General Plan Consistency.................................. 28

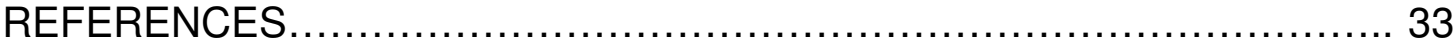

APPENDIX

City of South Lake Tahoe Draft Subdivision Ordinance................. 35 


\section{Chapter I}

\section{Introduction}

One of the most influential factors on land use patterns is the subdivision of land for development. Freilich and Shultz (1995) write that, "the pattern of a subdivison becomes the pattern of a community, which in turn may influence the character of an entire city" (p. 1). The design of subdivisions can have a great influence on how the community identifies with the neighborhood and how well connected it is to other parts of the community. It is very important for local jurisdictions to ensure that all new subdivisions are designed to further the community design goals for the area.

A subdivision is the division of a piece of property in to two or more parcels of land. Subdivision regulations govern the division of land into lots for building. Subdivision regulations "describe (1) the procedures that a subdivider must follow to obtain approval by a local government, (2) the criteria for the internal design of a subdivision, and (3) construction standards for public improvements in the subdivision" (ICMA, 2000. p. 362). The purpose of subdivision regulations is to create a record of the division of land in order to establish title descriptions and to ensure that all new buildable parcels have public improvements and services that are necessary when construction begins and before lots are sold. The rationale for government imposition of subdivision controls is based in the police power - the right of political entities to regulate in order to promote for the health, safety and general welfare of the community (Freilich \& Shultz, 1995, p. 28). 
In the early days of subdivision regulation the focus was on uniform surveying practices to create more accurate parcel descriptions, which would facilitate more consistent transfers of ownership and property assessment. In the $19^{\text {th }}$ century there was an increased concern for an oversupply of subdivided parcels, lack of quality in subdivision design and construction, and lack of public amenities, which led to additional regulations on land subdivision. The Standard City Planning Enabling Act (SCPEA), passed in1928, focused on standards for roadways, sidewalks, and lot sizes as a means to set minimum standards for public amenities (Ben-Joseph, 2003, pp. 11-13). In 1975 California adopted the Subdivsion Map Act (Map Act), which enabled local jurisdictions to regulate the subdivision of land. When the City of South Lake Tahoe first incorporated in 1965 the City adopted a subdivision ordinance that was essentially the same as the El Dorado County subdivision ordinance. In 1989 this ordinance was repealed because it was antiquated and not consistent with the subdivision regulations of the Tahoe Regional Planning Agency (TRPA). At the time, TRPA was working on a new subdivision chapter in their Code of Ordinances and the City intended to adopt the TRPA regulations, once it was approved by the TRPA Governing Board. To date, a new City ordinance has not been adopted. 
Tahoe Regional Planning Agency

TRPA is a bi-state regional agency that was created by the US Congress in 1969 for the purpose of protecting Lake Tahoe as a "national treasure for the benefit of current and future generations" (www.trpa.org). The establishment of the TRPA and regulations enforced by TRPA were a response to development within the Lake Tahoe Basin that impacted the natural beauty and ecological value of the Lake. Prior to 1955 the region was "...lightly populated with a few summer resorts, large estates and cottages along the lakeshore" (Twiss, 2004, p. 84). However, between 1955 and the early 1970's land subdivisions and development significantly increased. According to Robert Twiss (2004), prior to 1955 there were about 20,000 individual lots within the Tahoe Basin but in 1955 over 1000 new lots were created. In 1957, 2000 new vacant lots were created, in 1959, 2500 new lots, in 1960, 2800 new lots, in 1965, 3000 new lots, and in 1969, 4134 new lots were created. Between 1967 and 1972 the First Interstate Compact between California and Nevada was being written to give authority to TRPA to regulate land use in the Tahoe Basin. During this time the creation of TRPA, and development of the first regional plan for the Tahoe Basin was taking place. This led many land owners to rush to get subdivision and development approvals before the anticipated stricter regulations were adopted (Twiss, 2004, pp. 86-88). During this time, scientific evidence made it apparent that land development was causing significant environmental impacts to Lake Tahoe. These impacts included soil erosion, conveyance of soil and nutrients to the 
Lake, interception of ground water, alteration of stream channels, and destruction of wetlands (Twiss, 2004, p. 87).

In 1969, the first Interstate Compact was approved by both California and Nevada legislatures and signed by President Nixon. The first Compact placed the entire Lake Tahoe watershed under the jurisdiction of one agency rather than segregated between two states and among four counties and one city. The first Compact also gave comprehensive authority to TRPA to regulate all aspects of land use (Twiss, 2004, p. 87). Almost immediately, however, it was recognized that the first Compact had several weaknesses in protecting the Lake, one being the ability to grandfather previously subdivided lots and allow development on them. This approach would not address the environmental impacts of haphazard approvals that took place before comprehensive planning had occurred. In 1980, TRPA adopted the second bi-state compact that required adoption of environmental threshold and carrying capacity standards and a regional plan to guide orderly development in the Lake Tahoe Basin. A Regional Plan was adopted in 1984, but due to several lawsuits, it could not be implemented until 1987. The 1987 Regional Plan included the Individual Parcel Evaluation System (IPES) where individual existing lots were evaluated and ranked for development suitability to determine which lots could be built on. Along with these limitations on development of existing parcels, aggressive public acquisition programs were established to buy up many existing lots that were determined to be un-buildable (Twiss, 2004, p. 91). 
The 1984 Regional Plan also included a moratorium on future subdivisions that would create additional development potential. Goal 2, Policy 7 of the TRPA Goals and Policies, Land Use Element state that, "No new divisions of land shall be permitted within the region which would create new development potential inconsistent with the goals and policies of this plan (p.II-9)." It further states that the following types of subdivisions are consistent with the Plan as long as they do not create additional development potential,

A. Division of land for the purposes of conveying a portion thereof to a governmental agency, public entity, or public utility.

B. Division of land for the purposes of creating cemetery lots.

C. Division of land ordered by a federal or state court of competent jurisdiction as a result of bona fide, adversary legal proceedings to which the Agency is a party. Any such division of land or approval of any other project or action resulting from such legal proceedings, shall be pursuant to an evaluation of the effect of such division or approval upon the Regional Plan, the environmental thresholds, and other requirements of the Compact. Based on the above evaluation, appropriate adjustments to the Regional Plan shall be made.

D. A modification to an existing subdivision or a lot line adjustment or lot consolidation, which does not result in any increase in development potential, or in present or potential land coverage or density, and shall not have an adverse impact upon the health, safety, general welfare or environment of the Region. 
E. Conversion of an existing structure, to a stock cooperative, community apartment, condominium, or any other form of divided interest; which conversion does not result in any increase in development potential, or in present or potential land coverage or density, and will not have an adverse impact upon the health, safety, general welfare or environment of the Region.

F. Redivision, adjustment, or consolidation, of parcels within an existing urban area, as part of a TRPA approved redevelopment plan that does not increase development potential basin-wide.

G. Division of land through condominiums, community apartments, or stock cooperatives within an existing urban area in conjunction with the approval of a project associated with an approved transfer of development, or otherwise in accordance with the provisions of this Plan. In order to subdivide a project under this provision, the project itself shall be approved prior to the approval of the division and in no case shall the division result in a greater amount, a different location, or a greater rate of development than otherwise permitted by this Plan."

Specific regulations consistent with this policy were incorporated in to the TRPA Code of Ordinances in 1990. Any policies, programs, or regulations adopted by the City must be consistent with TRPA policy and ordinances. 


\section{Purpose of the Subdivision Ordinance}

Although the TRPA regulations prevent most subdivision types that create new lots and require extensive infrastructure, like what is more typical in the rest of California, there are still some types of subdivisions or subdivision related activities that are allowed. These often include condominium subdivisions, lot mergers and lot line adjustments as well as adjustments or verifications of past subdivisions through the map amendment or certificate of compliance process. Since the TRPA Code of Ordinances does allow for some types of subdivisions and the City does not have it's own subdivision ordinance, the City receives and reviews subdivision applications for compliance with the Subdivision Map Act. However, without a local subdivision ordinance, specific requirements for review procedure, subdivision design, and public improvements are not clear. In a discussion with City Engineering Division staff, it became apparent that there is concern about the lack of guidance for City staff and officials to influence the design of subdivisions or require infrastructure improvements (Hill, S. and Williams, A., personal communication, January 15, 2009). There is a lack of standards to support requirements that will ensure that public facilities serving the subdivision are safe and economical to maintain. There is also a lack of direction on how and when to coordinate with other agencies that have jurisdiction in the area or an interest in proposed subdivisions. Types of subdivisions that are still commonly proposed within the City include condominiums, hotel-condominiums, mobile home park subdivisions, parcel mergers, and lot line adjustments. 
Condominiums and Conversions of Existing Multi-Family Housing to Condominiums

TRPA Code of Ordinances Section 41.3.G allows for, "subdivision through condominiums, community apartments, or stock cooperatives, within an existing urban area, in con junction with the approval of a project associated with an approved transfer of development, or otherwise in accordance with the provisions of the Regional Plan and Code. In order to subdivide a project under this subsection, the project shall be new development approved pursuant to the 1987 Regional Plan, as amended, prior to the approval of the subdivision. The subdivision shall not result in a greater amount, a different location, or a greater rate of development than otherwise permitted by the Regional Plan and Code. Subdivisions under this subsection shall be reviewed and approved in accordance with the applicable provisions of Chapter 43 of this Code."

These types of new development subdivisions are becoming much more common as the market has favored condominium ownership as a means for providing lower cost, new construction, ownership opportunities for first time homebuyers or second home owners. New condominiums are first approved as multi-family projects then subdivided while being constructed. The approval as a multi-family project ensures that the subdivision is not creating any additional 
development potential beyond what would be allowed by the zoning. Most newly developed condominiums are in smaller condominium projects that consist of two or three buildings with yards delineated as common area. Since they typically are subdivisions that result in less than five sellable lots, they are not required to obtain a public report from the California Department of Real Estate and are not required to establish a home owners association (HOA). There is very little oversight on maintenance of common areas for these types of condominiums. In addition, without a subdivision ordinance, there is no policy or direction to require these condominium projects to establish an HOA. This has caused several concerns. Without an HOA, who is responsible for maintaining common areas and paying utility bills for common areas? How will the community ensure that development within the City is well maintained, safe, and aesthetically acceptable? There is also no codified guidance for potential developers to research the process or potential requirements of building condominiums before designing projects and submitting applications. The City of South Lake Tahoe Housing Element Background Report identified this as a constraint to the development of housing within the City (2007, p. 4-154).

The City Code does currently contain an Ordinance that applies to conversion of existing multi-family developments to condominiums and it provides guidance for the review process and standards to review the application by. Only one condominium conversion has occurred in the City since this ordinance was passed but the review went very smoothly since there were specific standards and procedures to follow. The ordinance also gave the 
property owner enough information so that he knew what to expect before submitting the application.

\section{Mobile Home Park Conversion}

There are several mobile home parks in the City of South Lake Tahoe, most of them are small and not well maintained, but not all. The current trend is that the smaller mobile home parks are being bought by new owners, closed and demolished then the land is developed with new condominiums. However, we have seen one of the larger and better maintained parks apply for conversion to resident ownership and subdivision of the mobile home sites in to individual lots. This application for conversion of the Tahoe Verde Mobile Home Park raised concerns over the potential for the park to no longer be affordable to its current residents and concerns over continued maintenance and the need for infrastructure upgrades in the park. Without a local City subdivision ordinance to provide guidance on these issues, review of the application became a political negotiation without clear guidelines except for the vague language of the State Subdivision Map Act.

\section{Hotel-Condominiums}

Another type of subdivision that the City is starting to see are condominium subdivisions where the condominiums are managed like hotels when the owners are not occupying them. This type of real estate product has become more popular in tourist areas where an owner may want to enjoy their 
condominium while on vacations but also want the convenience of a management company managing and maintaining the unit. Section 32-24.1 of the City Code does contain regulations related to the approval of condominium hotels. These regulations are focused on ensuring that the condominium hotel project will be high quality, well operated and maintained, and will not impact the City's transient occupancy tax revenues. The regulations limit the number of days per year that an owner can occupy the unit, in order to preserve the potential transient occupancy tax revenues that would be generated by the unit being rented on a nightly basis. These regulations are, however, focused on regulating the use and do not discuss the review and process for approval of a subdivision map that would create the individual condominium parcels.

\section{Smart Growth}

In August 2005 the City of South Lake Tahoe adopted smart growth principles that promote walkable mixed use centers, compact neighborhoods, and enhanced gateways. The Smart Growth Network defines smart growth principles as strategies aimed at creating neighborhoods that are "attractive, convenient, safe, and healthy" (2006). The Council directed that their smart growth principles would guide future land use and planning policies and thus provide a new direction for development patterns within the City. Subdivision regulations provide an opportunity to incorporate some of the smart growth principles in to future development. Although there are no subdivisions that create new neighborhoods occurring within the City, the types of subdivisions 
that are occurring do have an effect on the character of existing neighborhoods. Incorporating concepts that are guided by the City's Smart Growth Principles into the subdivision ordinance is important to ensure that neighborhoods are affected by new subdivisions in a way that takes steps towards and not away from the smart growth vision.

\section{Sustainability}

In November 2008 the City of South Lake Tahoe adopted it's Sustainability Plan. The Sustainability Plan builds on ten sustainability principles to outline goals and programs for green infrastructure, lake clarity, complete communities, environmentally friendly transportation, a vibrant local and regional economy, diverse housing, forest health and recreation, education, equity, community facilities, healthy local food system, and green building (2008, p. 7-8). By adopting the Sustainability Plan, the City made a commitment to continuously implementing and updating its goals for achieving results in these areas. Some of the goals include promoting transit use and walkability of neighborhoods, bicycle and pedestrian path connections, mixed uses and flexible buildings, energy efficient building design, and diversity of housing choices (City of South Lake Tahoe, 2008, p. 8-13). These principles can be incorporated in to subdivision design standards and requirements for improvements that will serve the subdivision residents and surrounding neighborhood. 


\section{Issues and Opportunities}

A review of literature regarding the history and effects of regulations on the subdivision of land reveal that there are some valid issues with them that need to be taken in to consideration. In a study completed by Eran Ben-Joseph he found that, "subdivision regulations and controls are seen both in the 1970s and in 2002 as the one aspect of regulation most responsible for unnecessarily increasing the cost of housing" (2003, p. 11). These regulation controls often lead to more expensive infrastructure improvements and costly delays during the review process. The cost of housing is a major concern in the City of South Lake Tahoe. The City's Housing Element Background Report prepared in 2008 found that the median house price for a single family home was $\$ 425,000$ in 2007 . The construction cost for building multi-family projects was approximately 2.5 times the cost of building somewhere else in California. These costs include, "land costs, entitlement costs, fees, best management practices, environmental protection, structural costs associated with snowload, and aesthetic enhancements..." (2007, p. 4-165). Often the cost of paying application and mitigation fees to the TRPA are cited as a major contributor to increased development costs in Tahoe and as a constraint to the development of housing (City of South Lake Tahoe, 2007, p. 4-142). Additional costs to new development that would be associated with offsite improvements could contribute to the high costs of housing development in the City. A subdivision ordinance would need to take in to account this potential adverse side effect. 
Development of housing can also become more expensive as a result of long administrative and approval processes (Ben-Joseph, E., 2003, p. 15). The study that Ben-Joseph conducted found that there has been an increase in the time it takes local jurisdictions to process subdivision applications over the last 25 years (2003, p. 15). Costly delays may be attributable to insufficient staffing of governmental agencies, long backlogs in processing, and antiquated procedures. Delays are increased when the developer must deal with multiple agencies to obtain permits and approvals (Schill, 2005, p. 12). A City subdivision ordinance could streamline and cut down on the processing time for subdivision applications by providing clear procedures for review and expectations for subdivision design and improvements. If this goal can be achieved, development costs associated with subdivision approval, that are potentially passed on to future buyers, could be reduced. 


\section{Chapter 2}

\section{Work Program}

The work program for this project includes researching literature related to subdivisions and smart growth as well as other local jurisdiction subdivision ordinances. Other ordinances that I will research include the El Dorado County, Town of Mammoth Lakes, Town of Truckee, and City of Arcata. The El Dorado County ordinance will be useful since they are also a local government agency with a portion of their jurisdictional area within the Lake Tahoe Basin. Also, the Town of Mammoth Lakes ordinance may provide some insight on how subdivisions are regulated in another tourist oriented, mountain community. More recently adopted subdivision ordinances that incorporate smart growth principles will provide some guidance on how smart growth can be accomplished through subdivision regulations. The work program will also include discussions and interviews with local officials and professionals that have direct experience with subdivisions in South Lake Tahoe. The final product will be a draft subdivision ordinance that could be considered by the City Planning Commission and City Council for adoption.

\section{Work Program Outline}

1. Prepare Background information - research

2. Identify the need for a subdivision ordinance in South Lake Tahoe research and discussions

a. Meet with City Engineer and staff 
3. Review subdivision ordinances from other local agencies - research

4. Prepare an outline of the ordinance to ensure it addresses all necessary content - writing

5. Review outline with stakeholders - discussion

a. Meet with City staff

6. Prepare draft ordinance - writing

\section{$\underline{\text { Review of Ordinances from Other Jurisdictions }}$}

I have reviewed the subdivision ordinances for the Town of Mammoth Lakes, Town of Truckee, El Dorado County, and the City of Arcata. My review of these ordinances was focused on how they might facilitate more efficient subdivision review and approval processes. The clarity of the review and approval process and the extent of the process both are big factors in how efficiently applications are processed. I also looked at whether the ordinances incorporate elements that would further smart growth or sustainability principles. Smart growth and sustainability features may include requirements for infrastructure that facilitates alternative forms of transportation, other than automobile or requirements for amenities within the subdivision that would put them closer to residences and reducing the need to travel longer distances to access them. These amenities could include recreation facilities, commercial uses, or other services. 


\section{i) Efficiency of Application Review}

These ordinances all contain procedural regulations that provide application requirements and determine who has the authority to review and approve subdivision applications. Although some of the general content of these subdivision ordinances are similar, there are some interesting differences in the details that could influence the efficiency of the review process. There are differences in who the approving authority is for different types of subdivision applications, differences in the type of subdivisions addressed, and differences in how specific each ordinance is on process and review timelines.

\section{Review Authority}

One of the goals for the City of South Lake Tahoe Subdivision Ordinance is to reduce the review and process time for complete applications. One important factor in this is which body has the approval authority for each type of application. Approval by bodies that have fixed meeting schedules can cause delay. Approvals by multi-person bodies such as Planning Commissions can also take longer because of quorum requirements and the need for majority votes. So, part of my review of subdivision ordinances from other jurisdictions focused on the delegation of approval authority for each type of application.

The following table shows the approving authority for different types of subdivision applications for each of the subdivision ordinances that I reviewed.

\begin{tabular}{|l|l|l|l|l|}
\hline \multicolumn{5}{|c|}{ Subdivision Application Approval Authority } \\
\hline & $\begin{array}{l}\text { El Dorado } \\
\text { County }\end{array}$ & $\begin{array}{l}\text { Town of } \\
\text { Mammoth }\end{array}$ & $\begin{array}{l}\text { Town of } \\
\text { Truckee }\end{array}$ & $\begin{array}{l}\text { City of } \\
\text { Arcata }\end{array}$ \\
\hline Tentative Map & Planning & Planning & Zoning & Zoning \\
\hline
\end{tabular}




\begin{tabular}{|l|l|l|l|l|}
\hline $\begin{array}{l}-4 \text { or fewer } \\
\text { parcels }\end{array}$ & Director & Commission & Administrator & Administrator \\
\hline $\begin{array}{l}\text { Tentative Map } \\
-5 \text { or more } \\
\text { parcels }\end{array}$ & $\begin{array}{l}\text { Planning } \\
\text { Commission }\end{array}$ & $\begin{array}{l}\text { Planning } \\
\text { Commission }\end{array}$ & $\begin{array}{l}\text { Planning } \\
\text { Commission }\end{array}$ & $\begin{array}{l}\text { Planning } \\
\text { Commission }\end{array}$ \\
\hline Parcel Map & $\begin{array}{l}\text { Planning } \\
\text { Director }\end{array}$ & N/A & $\begin{array}{l}\text { Planning } \\
\text { Director }\end{array}$ & $\begin{array}{l}\text { Zoning } \\
\text { Administrator }\end{array}$ \\
\hline Final Map & $\begin{array}{l}\text { Board of } \\
\text { Supervisors }\end{array}$ & $\begin{array}{l}\text { Planning } \\
\text { Commission }\end{array}$ & $\begin{array}{l}\text { Planning } \\
\text { Director }\end{array}$ & City Council \\
\hline $\begin{array}{l}\text { Lot Line } \\
\text { Adjustment }\end{array}$ & $\begin{array}{l}\text { Planning } \\
\text { Director }\end{array}$ & $\begin{array}{l}\text { Land Division } \\
\text { Review } \\
\text { Committee }\end{array}$ & $\begin{array}{l}\text { Planning } \\
\text { Director }\end{array}$ & $\begin{array}{l}\text { Zoning } \\
\text { Administrator }\end{array}$ \\
\hline Parcel Merger & N/A & N/A & $\begin{array}{l}\text { Planning } \\
\text { Director }\end{array}$ & $\begin{array}{l}\text { Zoning } \\
\text { Administrator }\end{array}$ \\
\hline $\begin{array}{l}\text { Certificate of } \\
\text { Compliance }\end{array}$ & $\begin{array}{l}\text { County } \\
\text { Surveyor or } \\
\text { Planning } \\
\text { Director }\end{array}$ & N/A & $\begin{array}{l}\text { Zoning } \\
\text { Administrator }\end{array}$ & $\begin{array}{l}\text { Zoning } \\
\text { Administrator }\end{array}$ \\
\hline
\end{tabular}

Most of the jurisdictions rely heavily on the Zoning Administrator or Planning Director to make decisions on all subdivisions except where there are five or more parcels involved. The Town of Truckee however, is the only jurisdiction where the Planning Director has the authority to approve Final Maps. The Planning Director approval of Final Maps streamlines the approval process because it is not bound by meeting schedules or majority votes. Truckee is unique because it also uses a Land Division Review Committee, which makes decisions on Lot Line Adjustments and makes recommendations to the Planning Commission on other subdivision applications. Including a separate review and recommending body in the process could cause the review process to take longer.

Parcel maps, parcel mergers, lot line adjustments, and certificates of compliance tend to have the lowest level of approval bodies. These types of 
subdivision activities do not typically have a large impact on the community or services. They also do not typically require major off-site improvements to support development within the subdivision. Delegating the review of these types of activities to lower approval authorities can reduce the length of the review process.

For tentative subdivision maps that involve subdivisions of four or fewer parcels the highest level of approval body in these four jurisdictions is the Planning Commission in the Town of Mammoth. The Map Act allows a local agency to designate an advisory agency to approve, conditionally approve, or disapprove a tentative map. However, if there is not local ordinance that authorizes it, then the map must be approved by the legislative body (Government Code §66452.1). Designating an advisory agency such as the Planning Commission or Zoning administrator to approve these maps could reduce the processing time.

All of the jurisdictions use the Planning Commission to approve large subdivision tentative maps. However, the approval authority of the Final map varies widely. The Map Act does allow for the authority to approve a Final Map to be delegated to "...the city or county engineer, surveyor, or other designated official" (Government Code $\S 66458(d)$ ) subject to requirements to notify the legislative body of the official's review. This is an application that primarily requires technical review of survey data and determining whether all conditions of the tentative map have been met as long as the final map is in substantial compliance with a previously approved tentative map. Due to the nature of this 
review, it makes sense that approval of this type of map could be conducted by a City Engineer or Surveyor, cutting down on processing time.

\section{Types of Subdivisions Addressed}

The four subdivision ordinances all contain specifics for tentative subdivision maps, parcel maps, final maps, and lot line adjustments. Not all of the ordinances address certificates of compliance or parcel merger applications and not all of the ordinances address conversion of existing residential structures and mobile home park subdivisions. The El Dorado County, Town of Truckee and the Town of Mammoth Lakes ordinances do not contain regulations for parcel mergers. Most often, parcel mergers reduce development potential rather than create new parcels for separate developments, therefore the need to regulate the design, improvements and services for these types of applications is reduced. Mergers require very little review and the documentation is relatively simple. However, without some direction on the review procedure within the ordinance this could create the potential for the procedure to become inconsistent and could cause confusion.

Certificates of Compliance also require very little review if complete and accurate information is provided with the application. It consists of the review of documentation to determine if existing parcels where legally created. Again, though, without some procedural direction and criteria for review, the staff would need to establish the procedures, they could be changed more often and confuse applicants. 
The Town of Mammoth and El Dorado County ordinances do not address conversions of existing residential structures to condominiums, community apartment or stock cooperatives. The Arcata and Truckee ordinances contain very detailed regulations for these types of conversions. The City of South Lake Tahoe already has a very detailed ordinance for residential conversions so it will not need to be addressed in the new subdivision ordinance.

None of the ordinances include regulations that are specific to subdivisions of mobile home parks. They each rely on the regulations of the Map Act for review of these subdivisions and do not include any special provisions for them.

\section{Smart Growth and Sustainability Elements}

I reviewed the subdivision ordinances to see if there are elements within them that would implement smart growth and sustainability goals. Smart growth principles include the goal of providing a variety of transportation choices. The types of things that I looked for were requirements for alternative transportation infrastructure and inclusion of recreation, commercial, or service amenities within the subdivision.

The types alternative transportation that I focused on, because it would be applicable to the City of South Lake Tahoe, are walking, bicycling, and bus transit. All of the ordinances contain standards for street design including sidewalks. The Arcata and Truckee ordinances are specific about requiring street lighting, pedestrian walkways, and landscaping. The Town of Truckee ordinance also specifically states that sidewalks that are detached from the curb 
and separated from the curb are preferred over curb adjacent sidewalks and the ordinance allows for gravel walkways to be installed, rather than sidewalks, where traffic is light. The El Dorado County ordinance does not include any requirements for the construction of sidewalks within a subdivision or on adjacent streets. The City of Arcata, Town of Mammoth Lakes, and Town of Truckee ordinances include requirements for bicycle and equestrian paths were it is appropriate. By reviewing the subdivision ordinances it is apparent that there is a wide range in the level of specificity when it comes to requirements for sidewalk and bicycle path improvements. The City ordinances put more emphasis on these types of improvements. None of the ordinances mention access to or facilities for bus transportation. The City of Arcata and Town of Truckee have incorporated more specific requirements and design standards for alternative transportation improvements, implying that they place a greater level of importance on them in the review of subdivision applications.

One of the key principles of smart growth is to mix land uses so that day to day services and amenities are accessible to residential areas. Some of these services and amenities include recreation areas, laundry services, coffee shops or cafes, and small-scale retail uses. Most of the ordinances address recreation areas by including the requirements from the Quimby Act (Chapter 4, Article 3 of the Map Act). This section of the Map Act provides details on when a local agency can require dedication of parkland or payment in lieu of dedication. The El Dorado County and City of Arcata Ordinances use the Quimby Act language almost verbatim. The Truckee ordinance also uses that same requirements as 
the Quimby Act but it is described very briefly. Requirements for parkland dedication apply to subdivisions of more than 50 parcels and in-lieu fees are applied to smaller subdivisions. The payment of in-lieu fees provides revenue to construct and maintain parkland but does not guarantee that the parkland will be in the vicinity of the particular subdivision that resulted in the payment of the fees. The Town of Mammoth Lakes ordinance includes a provision for dedication of parkland but leaves it as an optional requirement that the Planning Commission may impose on approval of a tentative map.

The Arcata ordinance also contains dedication requirements for public facilities such as schools and fire stations. The El Dorado County ordinance contains similar public dedication requirements. The Mammoth Lakes ordinance includes these requirements with the addition of public access dedications for access to recreation areas. The Town of Truckee is specific about dedications for public access to the Truckee River and Donner Lake.

None of the ordinances include requirements for mixed uses or including commercial amenities in subdivision design. However, the Arcata and Truckee ordinances also have standards for energy conservation and solar access. 


\section{Chapter III}

\section{Draft City of South Lake Tahoe Subdivision Ordinance}

The table of contents and full text of the City of South Lake Tahoe Draft Subdivision Ordinance (Draft Ordinance) is included at the end of this report. This section describes the Draft Ordinance and evaluates it for how well it achieves the goals of the project and its consistency with the City General Plan.

\section{Form and Content}

At first glance the Draft Ordinance has a traditional form and content that is typical of most subdivision ordinances in California. It contains direction for what type of application is necessary for different types of subdivision related activities, procedures for application submittal and review, and design standards for subdivisions. However, there are several unique aspects of the Draft Ordinance that should be discussed. First, the approval authority for all types of subdivision applications is with the City Engineer, except in the case of tentative maps for subdivisions of five or more parcels. Secondly, all of the subdivision design standards are oriented towards the design of condominium subdivisions, since the TRPA restrictions on creating new development potential cause condominiums to be the majority of subdivisions reviewed by the City. The third unique feature is that there is a small section that provides direction on the subdivision of mobile home parks. 


\section{Evaluation of Draft Ordinance}

This section discusses the extent that the draft ordinance does or does not achieve the goals discussed at the beginning of this report. These goals are to streamline the subdivision review and approval process, incorporate elements to promote smart growth and sustainability, and to be consistent with the City's General Plan goals, policies, and programs.

\section{Streamlined Process}

The Draft Ordinance provides a streamlined process simply by being adopted. By providing a direction on what is required with subdivision application submittal, what the review process is, and what findings must be made to approve subdivision activities, potential applicants will know what to expect before they decide to invest in their application. Providing clear direction is also beneficial for City staff to be able to process applications consistently and efficiently. In addition to providing this guidance, the Draft Ordinance is written to reduce processing time for applications. The most effective method of doing this is to place the approval authority with the City Engineer rather than with a decision making body that has a set meeting schedules and requirements for majority votes. In this Draft Ordinance the approval authority lies with the City Engineer for every type of subdivision related application except tentative maps for subdivisions that result in five or more parcels. In addition, the Draft Ordinance provides timelines for the City review of applications and deadlines for decisions on applications. This gives the applicants some assurance that the 
application will be processed within a designated timeline as long as the applicant has provided all of the information and materials for the application to be deemed complete. This has the potential to create a respectful relationship between applicants and City staff where expectations are clear on both sides and there are no costly surprises during the process.

\section{Smart Growth and Sustainability Elements}

The Draft Ordinance incorporates smart growth and sustainability concepts within the subdivision design and improvement requirements. Applicants may be required to provide infrastructure for pedestrian or bicycle circulation and street or walkway lighting which will contribute to the City's goal of promoting non-motorized transportation and may provide linkages where there are currently gaps in the circulation system. The improvements are only required within the subdivision boundaries or along adjacent right of ways where they will be utilized by residents of the subdivision. The Draft Ordinance also allows City staff to require drainage improvements that are integrated with the natural features of the property. A unique aspect of the Draft Ordinance, with respect to smart growth and sustainability, is that it requires condominium subdivisions of new development to be designed to incorporate one of the following features: 
- Building entrances oriented towards a central common area;

- Children's play areas;

- Bicycle path connected to existing bicycle paths;

- Special design or programs to promote the use of transit by residents;

- Passive solar design and incorporation of energy efficient devices;

- Public access to recreation areas;

- Live-Work unit design;

- Design to accommodate seniors or other special needs occupants;

- Alley-loaded parking;

- Deed restriction affordable or moderate income units.

By providing a menu of options for applicants to choose from they will be able to pick features that are most suitable to the type of design or amenity for their site and their project. It does not seem to be an unfair burden to require that only one of these features be designed in to each project. Because this regulation does not require elaborate green building or additional amenities, it should not add a significant amount of design or construction costs to each project. The menu approach also will facilitate variation in each project so that there are more options for purchasers to find a design that fits with their lifestyle and needs.

The City does not have the opportunity to require large parklands, open space, or public facilities within subdivisions because the subdivisions that occur within the City are relatively small, consist of few units, and are within a small project area. Unless a project is a part of a large redevelopment project there 
are very few opportunities for comprehensive planning of larger areas or consolidated parcels. As established by the US Supreme Court in the Dolan v. Tigard case in 1994, a local government can only require improvements and dedications where the requirement is proportional to the impact that the development is creating (Fulton, 1999, p. 186). The majority of privately proposed projects are so small that requiring these large amenities on site would not be proportional to the impact from the project. If in-lieu fees were imposed there would be additional costs to the subdivision project that may discourage the development of housing in the City.

\section{General Plan Consistency}

The City's current General Plan was last comprehensively adopted in 1999. In 2003 and again in 2008 the City updated the Housing Element of the General Plan. The City is currently in the process of completing a comprehensive update of the entire General Plan except for the newly adopted Housing Element. This analysis will evaluated the consistency of the Draft Ordinance with the currently adopted General Plan, including the 2008 Housing Element. The Housing Element, Circulation Element, and Land Use Elements contain several policies that relate to residential subdivisions. These policies are listed below along with a discussion of the Draft Ordinance's consistency or inconsistency with each policy. 


\section{Housing Element}

Policy 3-4 The City shall take all reasonable steps to ensure that proposed mobilehome park closures or subdivisions do not result in the displacement of persons of low and moderate income. In the case of closure or subdivision, mobile-home park owners shall be required to relocate low and moderate-income tenants and/or replace the lost low- and moderate income housing units.

Section 27-12 of the Draft Ordinance contains a small section related to mobilehome park subdivisions. This section primarily provides direction to comply with the requirements of the Map Act. These requirements include notification of mobilehome park residents at several stages before and during the subdivision review process. The Map Act also contains requirements for the subdivider to report the potential economic impacts of the subdivision on existing residents to the City Council and rent increase restrictions for tenants that do not choose to purchase their mobilehome lot. In addition, the Draft Ordinance requires owners of mobilehome parks that are proposing the subdivision to assist park residents in applying for financing through the state Mobilehome Park Resident Ownership Program and provide home buying education to residents. The draft Ordinance is consistent with, and implements this policy.

Policy 4-4 The City shall provide priority permit processing of projects which are targeted toward special needs groups, such as seniors, the disabled, and the homeless, including priority for 
building plan check, subdivision map review, improvement plans for roadways and utilities, and environmental impact analysis.

In Section 27-17 includes the requirement for City staff to place projects that are designed for special needs groups or are designed for green building certification at the front of the project review que. The draft Ordinance is consistent with, and implements, this policy.

Policy 6-2 The City shall encourage the use of energy conservation devices and passive design concepts which make use of natural climate to increase energy efficiency and reduce housing costs. Section 27-17 includes a requirement for condominium subdivision projects to include at least one of a list of features. One of those features is passive solar design and incorporation of energy efficient devices. The Draft Ordinance is consistent with, and implements, this policy.

Policy 7-4 The City shall ensure that adequate provisions are made in new developments of eight units or more for amenities, such as tot lots, play yards, child care, computer centers, etc., appropriate to the targeted resident population.

Section 27-17 of the Draft Ordinance includes the requirement for these amenities in condominium subdivisions of eight units or more. The draft Ordinance is consistent with, in implements, this policy. 
Policy 7-5 To create a balanced community, the City shall promote mixed-income neighborhoods by encouraging innovative design (e.g., second units, halfplexes, zipper lots, zero-lot lines, alleyloaded parking, six pack subdivisions, live-work units).

Section 27-17 includes a requirement for condominium subdivision projects to include at least one of a list of features. Two of these features are alley-loaded parking and units designed for live-work situations. The Draft Ordinance is consistent with, and implements, this policy.

\section{Circulation Element}

Plan for the land use changes and development patterns which will encourage the use of alternative transportation modes.

The Draft Ordinance contains several features that help to implement this policy. The subdivision design requirements include provisions to allow City staff to require sidewalk and bicycle path improvements where it is appropriate. As one of the features that may be incorporated in to the subdivision design, the applicant could also provide additional infrastructure and amenities for alternative transportation.

\section{Open Space Element}

Expand the amount of public access available to open space so as to provide low intensity outdoor recreation experiences and to act as buffers between more intensive use areas, with minimal environmental impact. 
Section 27-17 contains a requirement for subdivision designs to incorporate at least one of a list of amenities. This list includes public access to open space or recreation areas. The Draft Ordinance is consistent with, and implements, this policy. 


\section{References}

Ben-Joseph, E. (2003). Subdivision Regulations: Practices \& Attitudes. Lincoln Institute of Land Policy Working Paper.

City of Arcata. (2008). City of Arcata Municipal Code-Title 9-Land Use Code, Article 8.

City of South Lake Tahoe (1999, Housing Element 2008). City of South Lake Tahoe General Plan.

City of South Lake Tahoe. (2007). City of South Lake Tahoe Smart Growth Principles.

City of South Lake Tahoe. (2008). City of South Lake Tahoe Sustainability Plan.

Durkee, P., Scheidig, K., Beinke, M., Harbour, J.P., and Tunny, T.P. (2004). Map Act Navigator: A Practical and Tactical Guide to the Subdivision Map Act. Michael Patrick Durkee.

El Dorado County. (2004). El Dorado County Subdivision Ordinance, Title 16 El Dorado County Code.

Freilich, R.H. and Shultz, M.M. (1995). Model Subdivision Regulations: Planning and Law. Chicago, IL: American Planning Association.

Fulton, W. (1999). Guide to California Planning. Point Arena, CA: Solano Press Books.

Meck, S., Wack, P., and Zimet, M. (2000). Zoning and Subdivision Regulations. In Hoch, C., Dalton, L., and So, F. (Eds.). The Practice of Local Government Planning. (pp.343-374). Washington D.C.: International City/County Management Associaion.

Meck, S. (Ed.). (2002). Growing Smart Legislative Guidebook: Model Statutes for Planning and the Management of Change. (2002 Edition). Chicago, IL: American Planning Association.

Placer County. (2008). Placer County Code, Chapter 16 Subdivisions.

Schill, M.H. (2005). Regulations and Housing Development: What We Know. Cityscape: A Journey of Policy Development and Research, 8(1), 5-19.

Smart Growth Network. (2006). This is Smart Growth. 
Tahoe Regional Planning Agency. (2008). About TRPA. Retrieved December 20, 2008, from http://www.trpa.org/default.aspx?tabindex=0\&tabid=3.

Town of Mammoth Lakes. (2006). Subdivision Regulations, Municipal Code Title 17.

Twiss, R.H. (2004). Planning and land regulation at Lake Tahoe: Five decades of experience. In Lapping, M.B., and Furuseth, O.J. (Eds.). Big Places, Big Plans: Large-Scale Regional Planning in North America (pp. 83-95). Hampshire, UK: Ashgate Publishing. 


\section{APPENDIX}

\section{City of South Lake Tahoe Draft Subdivision Ordinance City Code Chapter 27}

Table of Contents

27-1 Administration

1. Title

2. Purpose

3. Applicability

4. Authority for Subdivision Decisions

27-2 Type of Approval Required

1. Tentative Map Required

2. Parcel and Final Map Required

27-3 Appeals

27-4 Violations and Enforcement

27-5 Tentative Map Filing and Approval

1. Purpose

2. Tentative Map Application

3. Evaluation of Application

4. Review and Decision

5. Findings Required for Tentative Map Approval

6. Effective Date

7. Time Limits

8. Time Extensions

9. Changes to Approved Tentative Maps or Conditions

27-6 Completion of Subdivision Process

27-7 Vesting Tentative Map

1. Application

2. Title

27-8 Parcel Maps

1. Purpose

2. Applicability

3. Form and Content

4. Filing

5. Review

6. Approval

7. Transmittal to Recorder

27-9 Final Maps

1. Purpose

2. Applicability

3. Form and Content

4. Filing

5. Review

6. Approval 
7. Map with Dedications

8. Map with Incomplete Improvements

9. Transmittal to Recorder

10. Supplemental Information

27-10 Amendments to Recorded Maps

1. Corrections

2. Changes to Approved Subdivisions

27-11 Condominiums

1. Purpose

2. Applicability

3. Application Filing and Review

27-12 Hotel-Condominiums

27-13 Mobile Home Parks

1. Conversions

2. Owner Assistance

27-14 Lot Line Adjustments

1. Purpose

2. Applicability

3. Filing an Application

4. Review

5. Approval

27-15 Parcel Merger

1. Purpose

2. Applicability

3. Fining an Application

4. Review

5. Approval

27-16 Certificates of Compliance

1. Purpose

2. Applicability

3. Filing an Application

4. Review

5. Approval

27-17 Subdivision Design and Improvements

1. Purpose

2. Applicability

3. Standards

4. Improvement Agreement and Security

5. Acceptance of Improvements

27-18 Dedications and Exactions

1. Purpose

2. Applicability

3. Reservations of Land for Public Facilities

4. Findings Required for Dedications and Exactions 


\section{City of South Lake Tahoe Subdivision Ordinance City Code Chapter 27}

\section{7-2. Administration}

1. Title. This Article shall be cited as the City of South Lake Tahoe Subdivision Ordinance.

2. Purpose. This article is enacted in accordance with the Subdivision Map Act, Sections 66410 et seq. of the California Government Code (hereafter referred to as the "Map Act"). The provisions of this ordinance are intended to supplement, implement, and work with the Map Act. This Article is not intended to replace the Map Act, and must be used in conjunction with the Map Act in the preparation of subdivision applications, and the review, approval, and improvement of proposed subdivisions. Further, this article is intended to promote public health, safety and general welfare, the orderly growth and development of the City.

3. Applicability. The subdivision of an existing parcel into two or more proposed parcels shall be first approved by the City. In general, the procedure for subdivision first requires the approval of a Tentative Map, and then the approval of a Parcel Map or Final Map to complete the subdivision process. The Tentative Map review process evaluates the compliance of the proposed subdivision with the standards of the City Code, Map Act, and the appropriateness of the proposed subdivision design. Parcel and Final Maps are precise engineering documents that detail the location and dimensions of all parcel boundaries in an approved subdivision and, after approval, are recorded in the office of the County Recorder. In the event of any conflicts between the provisions of this Chapter and the Map Act, the Map Act shall control.

4. Authority for Subdivision Decisions. The Community Development Director and City Engineer are authorized and directed to administer and enforce the provisions of this Article and applicable provisions of the Map Act for subdivisions within the City, except as otherwise provided by this Article.

a. Table 1 (Subdivision Review Authority) identifies the City official or authority responsible for reviewing and making decisions on each type of subdivision application and other decision required by this Article.

TABLE 1 - SUBDIVISION REVIEW AUTHORITIES

\begin{tabular}{|l|l|l|l|l|l|}
\hline Type of & Procedure & \multicolumn{4}{|c|}{ Role of Review Authority } \\
\cline { 3 - 6 } Subdivision & in & City & Zoning & Planning & City Council \\
& Section: & Engineer & Administrator & Commission & \\
\hline
\end{tabular}




\begin{tabular}{|l|l|l|l|l|l|}
\hline $\begin{array}{l}\text { Tentative } \\
\text { Map }-4 \text { or } \\
\text { fewer } \\
\text { parcels }\end{array}$ & $\mathrm{X}$ & & & \\
\hline $\begin{array}{l}\text { Tentative } \\
\text { Map }-5 \text { or } \\
\text { more parcels }\end{array}$ & & $\mathrm{X}$ & & $\mathrm{X}$ & \\
\hline Parcel Map & & $\mathrm{X}$ & & & \\
\hline Final Map & $\mathrm{X}$ & & & \\
\hline $\begin{array}{l}\text { Lot Line } \\
\text { Adjustment }\end{array}$ & $\mathrm{X}$ & & & \\
\hline $\begin{array}{l}\text { Parcel } \\
\text { Merger }\end{array}$ & & $\mathrm{X}$ & & & \\
\hline $\begin{array}{l}\text { Certificate of } \\
\text { Compliance }\end{array}$ & & $\mathrm{X}$ & & \\
\hline $\begin{array}{l}\text { Improvement } \\
\text { Plans }\end{array}$ & $\mathrm{X}$ & & & \\
\hline
\end{tabular}

27-2. Type of Approval Required

1. Tentative Map required. Map Act Section 66426 requires that any subdivision or resubdivision of land shall require the filing and approval of a Tentative Map.

2. Parcel and Final Map required. A Parcel or Final Map shall be required as follows:

a. Parcel Map. The filing and approval of a Parcel Map shall be required for a subdivision creating four or fewer parcels, with or without a designated remainder in compliance with Map Act Article 2, Chapter 1, except for the following:

(i) Public agency or utility conveyances. Any conveyance of land, including a fee interest, an easement, or a license, to a governmental agency, public entity, public utility or a subsidiary of a public utility for rights-of-way, unless the City Engineer determines based on substantial evidence that public policy necessitates a Parcel Map in an individual case.

b. Final Map. The filing and approval of a Final Map shall be required for a subdivision of five or more parcels.

27-3. Appeals. Any interested person may appeal any decision of the City Engineer or to the Planning Commission, and may appeal any decision of the Planning Commission to the Council, in compliance with Chapter 2, Article VIII (Appeals).

27-4. Violations and Enforcement. Any person who violates any provision of this Article shall be subject to the penalties specified by Map Act Division 2, Chapter 7, Article 1 and/or, where applicable, shall be guilty of a misdemeanor or infraction as specified in Chapter 9.96 (Enforcement and Penalties). 


\section{7-5. Tentative Map Filing and Review}

1. Purpose. This Chapter establishes requirements for the preparation, filing, approval or disapproval of Tentative Maps, consistent with the requirements of the Map Act.

\section{Tentative Map Application}

a. Tentative Map submittal shall include the application forms, and all information and other materials as required by the Community Development Department and the City Engineer.

b. Tentative Map application must be accompanied by an application fee as set forth in the City of South Lake Tahoe Master Fee Schedule.

c. The Tentative Map shall clearly show the following data:

i) Owner of record (name and address),

ii) Name of applicant (name and address),

iii) Map prepared by (name and address),

iv) Section, township and range,

v) Date of map preparation;

vi) Vicinity map;

vii) North arrow and scale;

viii) The locations and names of any adjacent right of ways;

ix) Topographic contours at 5' intervals;

$x)$ Boundaries of the subdivision;

xi) Width and approximate location of any existing or proposed easements;

xii) Approximate area and dimensions for all proposed parcels;

xiii) Names of adjacent subdivisions and adjacent parcel map information;

xiv) Current assessors parcel map information for the subdivision area;

$x v)$ Locations of any existing structures;

xvi) All proposed utility providers;

xvii) Any natural hazard areas, and any flood-prone or special flood hazard areas and the base flood elevation, as applicable;

$x$ viii) Proposed structural fire protection.

\section{Evaluation of Application}

a. Tentative Map applications will first be reviewed for completeness. Within 30 days of the application submittal, City staff will notify the applicant if any additional materials or information is necessary for review and processing of the application.

b. During the 30 day completeness review period, City staff will evaluate the application for compliance with the California Environmental Quality Act and notify the applicant of the results 
of that initial review and whether additional environmental review is necessary.

\section{Review and Decision}

a. Once deemed complete, the application will be referred to other agencies that will be expected to provide services to the subdivision. This includes, as appropriate, City departments, County agencies, other local agencies, state agencies, public utilities and the Tahoe Regional Planning Agency. An agency wishing to respond to a referral shall provide the Department with its recommendations within 15 days after receiving the Tentative Map application.

b. City staff will, review and evaluate each Tentative Map as to its compliance and consistency with applicable provisions of the SLTCC, the General Plan, any applicable community plan, and the Map Act; Determine the extent to which the proposed subdivision complies with the findings in Section 9.81.060 (Findings Required for Tentative Map Approval); and

i) Prepare a staff report to the review authority describing the conclusions of the evaluations of the map, and recommending to the review authority the approval, conditional approval, or denial of the Tentative Map. The staff report shall be delivered to the subdivider at least three days before any hearing or action on the Tentative Map by the review authority.

ii) Where the review authority is the Planning Commission there shall be a public hearing on the proposed Tentative Map. The authority shall consider the recommendations of the City staff, any agency comments on the map, and any public testimony.

iii) Within 50 days after the Tentative Map application was deemed complete the review authority shall approve, conditionally approve, or deny the Tentative Map.

iv) Approval or conditional approval of a Tentative Map shall be given only after the review authority first makes all findings required by Section 27-5.5 (Findings required for Tentative Map Approval). The review authority may include conditions of approval were necessary to ensure compliance with applicable regulations or to protect the health, safety, and welfare of the community.

\section{Findings Required for Tentative Map Approval}

a. In determining whether to approve a Tentative Map, the City shall apply only those ordinances, policies, and standards in effect at the date that City staff determined that the application was complete, except where the City has initiated General Plan, specific plan or SLTCC changes, and provided public notice as required by Map Act Section 66474.2. 
b. The review authority may approve a Tentative Map only after first making all of the following findings. The findings shall apply to each proposed parcel as well as the entire subdivision, including any parcel identified as a designated remainder in compliance with Map Act Section 66424.6.

i) The proposed subdivision, including its design and improvements, is consistent with the General Plan and any applicable Community Plan;

ii) The site is physically suitable for the type and proposed density of development;

iii) The design of the subdivision and the proposed improvements will not cause substantial environmental damage or injure fish or wildlife or their habitat;

iv) The design of the subdivision and type of improvements will not cause serious public health or safety problems;

v) The design of the subdivision and the type of improvements will not conflict with easements acquired by the public at large for access through or use of, property within the proposed subdivision. This finding may also be made if the review authority finds that alternate easements for access or use will be provided, and that they will be substantially equivalent to ones previously acquired by the public. This finding shall apply only to easements of record, or to easements established by judgment of a court of competent jurisdiction, and no authority is hereby granted to the review authority to determine that the public at large has acquired easements of access through or use of property within the proposed subdivision;

vi) The discharge of sewage from the proposed subdivision into the community sewer system will comply with any applicable requirements prescribed by the California Regional Water Quality Control Board;

vii) A preliminary soils report or geological hazard report indicates no adverse soil or geological conditions and the subdivider has provided sufficient information to the satisfaction of the City Engineer or other applicable review authority that any adverse conditions will be corrected in the plan for the development; and viii)The proposed subdivision is consistent with all applicable provisions of the SLTCC and the Subdivision Map Act. 
6. Condominiums. Any applicable findings required by Section 32-20 for condominium conversions.

7. Effective Date. The approval of a Tentative Map shall become effective immediately after the expiration of the appeal period for the decision.

8. Time Limits. An approved Tentative Map is valid for 24 months after its effective date, except as otherwise provided by Map Act Sections 66452.6, 66452.11, 66452.13, or 66463.5. Expiration of an approved Tentative Map or vesting Tentative Map shall terminate all proceedings. The application shall not be reactivated unless a new Tentative Map application is filed. At the end of 24 months, the approval shall expire and become void unless:

a. A Parcel or Final Map, and related bonds and improvement agreements, have been filed with the City Engineer in compliance with Section 27-8 or 27-9 (Parcel Maps and Final Maps); or

b. An extension of time has been granted in compliance with Section 27-5.8.

9. Time Extensions. When a subdivider has not completed all Tentative Map or Vesting Tentative Map conditions of approval and filed a Parcel or Final Map with the City within the time limits established by Section 27-5.7, time extensions may be granted in compliance with this Section.

a. Filing of extension request. An extension request shall be in writing and shall be filed with the Engineering Division on or before the date of expiration of the approval or previous extension, together with the required filing fee.

b. Approval of extension. The original review authority may grant one 12-, 24-, or 36-month extension to the initial time limit, only after finding that:

i) There have been no changes to the provisions of the General Plan, any applicable Community Plan or the SLTCC applicable to the project since the approval of the Tentative Map;

ii) There have been no changes in the character of the site or its surroundings that affect how the policies of the General Plan or other standards of the SLTCC apply to the project; and

iii) There have been no changes to the capacities of community resources, including but not limited to water supply, sewage treatment or disposal facilities, roads or schools so that there is no longer sufficient remaining capacity to serve the project.

c. A time extension of more than 36 months may be granted only in compliance with Map Act Section 66452.6 or 66463.5.

\section{Changes to Approved Tentative Maps or Conditions}


a. Application for changes. The subdivider shall file an application and filing fee with the Engineering Division, using the forms furnished by the Engineering Division, together with the following additional information:

i) A statement identifying the Tentative Map number, the features of the map or particular conditions to be changed and the changes requested, the reasons why the changes are requested, and any facts that justify the changes; and

ii) Any additional information deemed appropriate by the Engineering Division or Planning Division.

b. Processing. Proposed changes to a Tentative Map or conditions of approval shall be processed in the same manner as the original Tentative Map.

c. Findings for approval. The review authority shall not modify the approved Tentative Map or conditions of approval unless it shall first find that the change is necessary because of one or more of the following circumstances, and that all of the applicable findings for approval required by subsections $9.81 .060 \mathrm{~A}$ and $\mathrm{B}$ can still be made:

i) There was a material mistake of fact in the deliberations leading to the original approval;

ii) There has been a change of circumstances related to the original approval; or

iii) A serious and unforeseen hardship has occurred, not due to any action of the applicant subsequent to the enactment of the SLTCC.

27-6. Completion of Subdivision Process. After approval of a Tentative Map pursuant to this Chapter, the subdivider shall proceed to fulfill the conditions of approval within any time limits specified by the conditions and the expiration of the map and, where applicable, shall prepare, file and receive approval of improvement plans in compliance with City Engineering Standards before constructing any improvements.

1. A parcel or final map shall be prepared, filed, and processed in compliance with Section 27-8 or 27-9.

27-7. Vesting Tentative Maps. Whenever the SLTCC requires that a Tentative Map be filed, a vesting Tentative Map may instead be filed, provided that the vesting Tentative Map is prepared, filed and processed in compliance with this Section.

1. Application. The vesting Tentative Map shall include the following information in addition to that required by Section 27-5 (Tentative Map Filing and Approval). The vesting Tentative Map shall be prepared with the words "Vesting Tentative Map" printed conspicuously on its face.

\section{7-8. Parcel Maps}


1. Purpose. This Chapter establishes requirements for the preparation, filing, approval and recordation of Parcel Maps, consistent with the requirements of the Map Act.

2. Applicability. A Parcel Map shall be filed and approved to complete the subdivision process for a subdivision of four or fewer parcels.

3. Form and Content. A Parcel Map shall be prepared by or under the direction of a qualified, registered civil engineer or licensed land surveyor, registered or licensed by the State of California. Parcel Map submittal shall include the application forms, and all information and other materials prepared as required by the Engineering Division and Planning Division. Parcel maps shall conform to the following:

a. The map shall be legibly drawn, printed or reproduced by a process assuring a permanent record in black on durable, transparent material. The map shall be made and shall be in such condition when filed so that legible prints may be made from it. An eight-and-one-half inch by eleven inch reduced copy of each sheet shall be delivered to the City Engineer or supplied electronically.

b. Sheet key. The particular number of the sheet and the total number of sheets comprising the map shall be stated on each of the sheets.

c. Miscellaneous data. Each sheet of the map shall state the number and name, if any, of the subdivision, the scale, and north point.

d. Survey data. The map shall show all survey data necessary to locate all monuments and to locate or retrace all interior and exterior boundary lines, lot lines, and block lines appearing on the map, including bearings and distances, to the nearest onehundredth foot, of straight lines, and radii and arc length or chord bearings and length for all curves, and such information as may be necessary to determine the location of the centers of curves and ties to existing monuments used to establish subdivision boundaries.

e. Monuments. The map shall show monuments found or set in the manner described in subsection $d$. of this Section. If monument setting has been deferred, the map shall note which monuments are in place and which are to be set.

f. Vicinity map. The map shall show the definite location of the subdivision, particularly in relation to surrounding surveys.

g. Lot numbering. Lots shall be numbered consecutively beginning with the numeral "1" and continuing without omission or duplication throughout the entire subdivision. No prefix or suffix or combination of letter and number shall be used. Each lot shall be shown entirely on one sheet.

h. Boundary lines. The boundary lines of the subdivision shall be clearly identified and emphasized by appropriate line weight. 
The tract boundary shall be based on record data on file at the office of the county recorder and must be reestablished by methods commonly accepted in the field of surveying and in accordance with state law. The method of survey shall be clearly indicated on the map. Any City boundary crossing or adjoining the subdivision shall be shown on the map.

i. Easements. The centerline or side lines of each easement to which the lots in the subdivision are subject shall be shown upon the map. If such easement cannot be definitely located from the records, a statement showing the existence of such easement shall be placed on the title sheet of the map and the approximate location shall be shown. All easements shall be designated on the map by fine dotted lines. Each easement shall be clearly labeled, identified and marked as to nature and purpose, and, if already of record, its record reference shall be shown. If not of record, a statement of such easement shall be placed on the title sheet of the map. If such easement is being dedicated by the map, it shall be properly set out in the owner's certificate and dedication on the title sheet of the map.

j. Watercourses. All watercourses, storm drains and areas subject to inundation during a one-hundred year storm shall be outlined and marked on the map. Elevations of floodwater based on City datum shall be noted on the map. All other natural watercourses or bodies of water shall also be delineated. The top of bank for water courses and the the extent of any riparian vegetation along the watercourses shall be shown, based on a field survey.

k. Hazard areas. If any part of an area to be subdivided, lot or parcel, is subject to flood hazard, inundation, or geological hazard, or located in a fault zone, it shall be clearly shown on the map by a prominent note on each sheet whereon such conditions exist.

I. Not a part. All areas shown on the map which do not constitute a part of the subdivision shall be labeled "not a part of this subdivision" or "N.A.P.O.T.S." All lines delineating those areas shall be dashed.

$\mathrm{m}$. Remainder. When a subdivision is of a portion of any unit or units of improved or unimproved land, the map may designate as a remainder that portion which is not divided for the purpose of sale, lease, or financing. If so designated, such remainder parcel shall be treated as set out in Section 66424.6 of the Subdivision Map Act or its successor section, as it may be amended from time to time.

4. Filing. The Parcel Map, together with all data, information and required materials, and required application fee established by the City Master fee Schedule, shall be submitted to the City Engineer. The Parcel Map 
shall be considered submitted when it is complete and complies with all applicable provisions of this Article and the Map Act.

\section{Review}

a. If the Parcel Map does not conform as required above, the subdivider shall be notified within 30 days of the incomplete submittal, and given the opportunity to make necessary changes and resubmit the Parcel Map, together with all required data, if the Tentative Map has not expired.

b. Once the application is deemed complete, within 30 days, the City Engineer shall:

i) Determine whether all applicable provisions of the SLTCC and the Map Act have been complied with, that the map is technically correct, and that it is in substantial compliance with the approved Tentative Map; and

ii) Obtain verification from the Community Development Department that the Parcel Map conforms to the approved Tentative Map and that any conditions of approval for which that office is responsible have been completed.

\section{Approval}

a. The City Engineer may accept or reject dedications and offers of dedication that are made by a statement on the Parcel Map in compliance with Map Act Section 66463(b).

b. After approval of a Parcel Map, the City Engineer shall transmit the map to the County Recorder for filing in compliance with Map Act Section 66450.

27-9. Final Maps. A Final Map shall be filed and approved to complete the subdivision process for a subdivision of five or more parcels.

1. Purpose. This Chapter establishes requirements for the preparation, filing, approval and recordation of Final Maps, consistent with the requirements of the Map Act.

2. Applicability. A Final Map shall be filed and approved to complete the subdivision process for a subdivision of five or more parcels.

3. Final Map Form and Content. A Final Map shall be prepared by or under the direction of a qualified registered civil engineer or licensed land surveyor, registered or licensed by the State of California. Final Map submittal shall include all information and other materials prepared as required by the Engineering and Planning Division. A Final Map submittal shall also include a digital copy of the Final Map, prepared using computer software and standards specified by the City Engineer.

a. The map shall be legibly drawn, printed or reproduced by a process assuring a permanent record in black on durable, transparent material. The map shall be made and shall be in such condition when filed so that legible prints may be made from it. An eight-and-one-half inch by eleven inch reduced copy 
of each sheet shall be delivered to the City Engineer or supplied electronically.

b. Sheet key. The particular number of the sheet and the total number of sheets comprising the map shall be stated on each of the sheets.

c. Miscellaneous data. Each sheet of the final subdivision map shall state the number and name, if any, of the subdivision, the scale, and north point.

d. Survey data. The map shall show all survey data necessary to locate all monuments and to locate or retrace all interior and exterior boundary lines, lot lines, and block lines appearing on the final map, including bearings and distances, to the nearest one-hundredth foot, of straight lines, and radii and arc length or chord bearings and length for all curves, and such information as may be necessary to determine the location of the centers of curves and ties to existing monuments used to establish subdivision boundaries.

e. Monuments. The map shall show monuments found or set in the manner described in subsection $d$. of this Section. If monument setting has been deferred, the map shall note which monuments are in place and which are to be set.

f. Vicinity map. The final subdivision map shall show the definite location of the subdivision, particularly in relation to surrounding surveys.

g. Lot numbering. Lots shall be numbered consecutively beginning with the numeral "1" and continuing without omission or duplication throughout the entire subdivision. No prefix or suffix or combination of letter and number shall be used. Each lot shall be shown entirely on one sheet.

h. Boundary lines. The boundary lines of the subdivision shall be clearly identified and emphasized by appropriate line weight. The tract boundary shall be based on record data on file at the office of the county recorder and must be reestablished by methods commonly accepted in the field of surveying and in accordance with state law. The method of survey shall be clearly indicated on the final map. Any City boundary crossing or adjoining the subdivision shall be shown on the map.

i. Watercourses. All watercourses, storm drains and areas subject to inundation during a one-hundred year storm shall be outlined and marked on the map. Elevations of floodwater based on City datum shall be noted on the map. All other natural watercourses or bodies of water shall also be delineated. The top of bank for water courses and the the extent of any riparian vegetation along the watercourses shall be shown, based on a field survey.

j. Hazard areas. If any part of an area to be subdivided, lot or parcel, is subject to flood hazard, inundation, or geological 
hazard, or located in a fault zone, it shall be clearly shown on the final map by a prominent note on each sheet whereon such conditions exist.

k. Not a part. All areas shown on the final subdivision map which do not constitute a part of the subdivision shall be labeled "not a part of this subdivision" or "N.A.P.O.T.S." All lines delineating those areas shall be dashed.

I. Hazard areas. If any part of an area to be subdivided, lot or parcel, is subject to flood hazard, inundation, or geological hazard, or located in a fault zone, it shall be clearly shown on the final map by a prominent note on each sheet whereon such conditions exist.

m. Not a part. All areas shown on the final subdivision map which do not constitute a part of the subdivision shall be labeled "not a part of this subdivision" or "N.A.P.O.T.S." All lines delineating those areas shall be dashed.

$\mathrm{n}$. Remainder. When a subdivision is of a portion of any unit or units of improved or unimproved land, the map may designate as a remainder that portion which is not divided for the purpose of sale, lease, or financing. If so designated, such remainder parcel shall be treated as set out in Section 66424.6 of the Subdivision Map Act or its successor section, as it may be amended from time to time.

\section{Filing}

a. Filing with City Engineer. The Final Map, together with all data, information and materials required by the Engineering Division shall be submitted to the City Engineer. The Final Map shall be considered submitted when it is complete and complies with all applicable provisions of this Chapter and the Map Act.

b. If the Final Map does not conform as required above, the subdivider shall be notified within 30 days of the application being deemed incomplete, and given the opportunity to make necessary changes.

5. Review. The City Engineer shall review the Final Map and all accompanying materials, and shall:

a. Determine whether all applicable provisions of the SLTCC and the Map Act have been complied with, that the map is technically correct, and that it is in substantial compliance with the approved Tentative Map; and

b. Obtain verification from the Community Development Department that the Final Map conforms to the approved Tentative Map and that any conditions of approval for which that office is responsible have been completed.

c. Multiple Final Maps. Multiple Final Maps may be filed if the subdivider included a statement of intention with the Tentative Map that he or she would submit multiple phased Final Maps. 
6. Approval. After determining that the Final Map is in compliance and is technically correct in compliance with Section 27-9.3, the City Engineer shall execute the City Engineer's certificate on the map in compliance with Map Act Section 66442, and forward the Final Map to the Planning Commission for action, as follows.

a. Review and approval by Planning Commission. The Planning Commission shall approve or disapprove the Final Map at its next regular meeting after receiving the map, or at its next regular meeting after the meeting at which it receives the map, unless that time limit is extended with the mutual consent of the City Engineer and the subdivider.

b. Criteria for approval. The Planning Commission shall approve the Final Map if it conforms to all the requirements of the Map Act, all provisions of the SLTCC that were applicable at the time that the Tentative Map was approved, and is in substantial compliance with the approved Tentative Map.

c. Approval by inaction. If the Planning Commission does not approve or disapprove the Final Map within the prescribed time or any authorized extension, and the map conforms to all applicable requirements, it shall be deemed approved, and the City Clerk shall certify its approval on the map.

7. Map with Dedications. If a dedication or offer of dedication is required on the Final Map, the Planning Commission shall accept, accept subject to improvement, or reject with or without prejudice any or all offers of dedication, at the same time as it takes action to approve the Final Map. If the Planning Commission rejects the offer of dedication, the offer shall remain open and may be accepted by the Planning Commission at a later date pursuant to Map Act Section 66477.2. Any termination of an offer of dedication shall be processed in compliance with Map Act Section 66477.2 and the street vacation procedure.

8. Map with Incomplete Improvements. If improvements required by the SLTCC, conditions of approval, or other law have not been completed at the time of approval of the Final Map, the Planning Commission shall require the subdivider to enter into an agreement with the City as specified in Map Act Section 66462, and Section 2716.4 (Improvement Agreements and Security), as a condition precedent to the approval of the Final Map.

9. Transmittal to Recorder. After action by the Planning Commission, and after the required signatures and seals have been affixed, the City Engineer shall transmit the Final Map to County Recorder for filing.

10. Supplemental Information. Additional information may be required to be submitted and recorded simultaneously with a Final Map as required by this Section.

a. Preparation and form. The additional information required by this Section shall be presented in the form of additional map sheets, unless the Community Development Director or City 
Engineer determines that the type of information required would be more clearly and understandably presented in the form of a report or other document. The additional map sheet or sheets shall be prepared in the same manner and in substantially the same form as required for Parcel Maps by Section 27-9.3 (Final Map Form and Content).

b. Content of information sheets. Supplemental information sheets shall contain the following statements and information:Title. A title sheet, including the number assigned to the accompanying Final Map by the City Engineer, the words "Supplemental Information Sheet;"

c. Explanatory statement. A statement following the Title sheet that the supplemental information sheet is recorded along with the subject Final Map, and that the additional information being recorded with the Final Map is for informational purposes, describing conditions as of the date of filing, and is not intended to affect record title of interest;

d. Location map. A location map, at a scale not to exceed one inch equals 2,000 feet. The map shall indicate the location of the subdivision within the City;

e. Soils or geologic hazards reports. When a soils report or geological hazard report has been prepared, the existence of the report shall be noted on the information sheet, together with the date of the report and the name of the engineer making the report; and

f. Information required by conditions of approval. Any information required by the review authority to be included on the supplemental information sheets because of its importance to potential successors in interest to the property, including any other easements or dedications.

27-10. Amendments to Recorded Maps. A recorded Parcel or Final Map shall be modified to correct errors in the recorded map or to change characteristics of the approved subdivision only as set forth in this Section.

1. Corrections. In the event that errors in a Parcel or Final Map are discovered after recordation, or that other corrections are necessary, the corrections may be accomplished by either the filing of a certificate of correction or an amending map, in compliance with Chapter 3 , Article 7 of the Map Act. For the purposes of this Section, "errors" include errors in course or distance (but not changes in courses or distances from which an error is not ascertainable from the Parcel or Final Map), omission of any course or distance, errors in legal descriptions, or any other map error or omission as approved by the City Engineer that does not affect any property right, including but not limited to lot numbers, acreage, street names, and identification of adjacent record maps. Other corrections may include indicating 
monuments set by engineers or surveyors other than the one that was responsible for setting monuments, or showing the proper character or location of any monument that was incorrectly shown, or that has been changed.

2. Changes to Approved Subdivisions. In the event that a subdivider wishes to change the characteristics of an approved subdivision, including but not limited to the number or configuration of parcels, location of streets or easements, or the nature of required improvements, the construction of which has been deferred through the approval of an agreement in compliance with Section 27-16.4 (Improvement Agreements and Security), a new tentative and Parcel or Final Map shall be filed and approved as required by Section 27-2 (Type of Subdivision Approval Required).

\section{7-11. Condominiums.}

1. Purpose. This Chapter establishes requirements for applications for the creation of a condominium simultaneously with the construction of a new structure.

2. Applicability. The provisions of this Chapter apply to new construction of new common interest developments, including community apartment projects, condominiums, planned developments, stock cooperatives, etc. As a type of real property ownership, a condominium may include a variety of development types, including apartment-type structures, mobile home parks, townhouses, etc. The conversion of an existing structure to a condominium, consistent with the requirements of the Map Act must be in compliance with City Code Section 32-20.

3. Application. When a residential structure is proposed at the time of construction as a condominium, community apartment project, or stock cooperative, a Tentative Map for the project shall be filed in the same form, have the same contents and accompanying data and reports and shall be processed, approved or denied in the same manner in compliance with Section 27-5 (Tentative Map Filing and Processing). Section 27-8 and 27-8 (Parcel Maps and Final Maps) determines whether a Parcel or Final Map shall also be filed.

27-12. Hotel-Condominiums. Subdivisions of Hotel-Condominiums must comply with the procedures and standards of this Chapter as well as SLTCC Section 3224.1.

\section{7-13. Mobile Home Parks}

1. Conversion. An application for conversion of a mobile home park to resident ownership shall comply with the Map Act (Government Code Section 66427) including all noticing of existing tenants, rights of tenants for purchase of condominium lots, and avoidance of economic displacement of nonpurchasing tenants. In the case of subdividing a mobile home park in to a condominium, community apartment or stock cooperative project, the subdivision must comply with all noticing requirements of the Map Act (Government Code Section 66452). 
2. Owner Assistance. Where the subdivision of a mobile home park is initiated by the owner of the park, the City may require the owner to assist park residents to apply for financing through the state Mobilehome Park Resident Ownership Program and to provide home buyer education to residents.

\section{7-14. Lot Line Adjustments}

1. Purpose. This Chapter provides procedures for the preparation, filing, review, and approval or denial of applications for Lot Line Adjustment, in compliance with the Map Act (Government Code Section 66412(d)).

2. Applicability. The Lot Line Adjustment procedure shall be used only for the purpose of relocating lot lines between two or more adjoining parcels, where land taken from one parcel is added to an adjacent parcel and where no more parcels are created than originally existed. For the purposes of this Chapter, an "adjacent parcel" is one that directly touches at least one of the other parcels involved in the adjustment.

3. Filing an Application. An application for a Lot Line Adjustment shall be filed with the Engineering Division and shall include the information required by the Engineering Division, together with the processing fee specified by the City Master Fee Schedule.

4. Review. The parcels proposed in a Lot Line Adjustment shall be designed to conform with all applicable standards of SLTCC Chapters 5 and 32; except that an adjustment involving existing nonconforming parcels and/or parcels with existing nonconforming development may be approved provided that:

a. The adjustment will not have the effect of creating a greater number of nonconforming parcels than exist before adjustment and will not cause a parcel that was nonconforming before the adjustment to become more nonconforming as a result of the adjustment, except where the review authority determines that the adjustment will substantially improve the conditions of the pre-adjustment parcel and development;

b. Any existing conforming development on a parcel will not become nonconforming as a result of the adjustment; and

c. Where existing development was nonconforming before the adjustment, the adjustment itself will not increase the nonconformity, except where the review authority determines that the adjustment will substantially improve the conditions of the pre-adjustment parcel and development.

5. Approval. After consultation with the Community Development Director, the City Engineer shall approve a lot line adjustment provided that all criteria identified in Map Act Section 66412(d) are met to the City Engineer's satisfaction. After City approval, the applicant shall be responsible for recording the approval document and paying the necessary fees charged by the County Recorder for recording Lot Line Adjustment approval documents in compliance with the Map Act. 


\section{7-15. Parcel Merger}

1. Purpose. Upon request of the legal owner of contiguous parcels created by subdivision, the planning director may approve pursuant to Government Code Section 66499.20 3/4, the merger of the parcels without reverting to acreage. In approving the combination of parcels, the City Engineer or Community Development Director may impose reasonable conditions.

2. Applicability. The Parcel Merger procedure shall be used only for the purpose of merging two or more existing parcels.

3. Filing an Application. Any such request shall be in writing signed by all owners and accompanied by any such data, documents or maps as may be required by the City Engineer, including a legal description of the newly combined parcel, to illustrate or legally describe the proposed configuration.

4. Review and Processing. The resulting parcels proposed in a merger shall be designed to conform with all applicable standards of SLTCC Chapters 5 and 32; except that a merger involving existing nonconforming parcels and/or parcels with existing nonconforming development may be approved provided that:

a. Where existing development or parcels was nonconforming before the merger, the merger itself will not increase the nonconformity, except where the review authority determines that the merger will substantially improve the conditions of the pre-adjustment parcel and development.

5. Approval. Upon approval, a certificate of merger in a form approved by the City Attorney shall be recorded with the county recorder. The filing of the certificate of merger shall constitute legal merger of the land affected thereby.

\section{7-16. Certificates of Compliance}

1. Purpose. Pursuant to Section 66499.35 of the Subdivision Map Act, any owner of a parcel of land may request the local agency to determine if their parcel complies with the subdivision map act and any local ordinance enacted pursuant thereto. This article sets forth the standards that City staff will use to determine if the parcel complies with the subdivision map act and local ordinances.

2. Applicability. A certificate of compliance is a document issued pursuant to Government Code section 66499.35 and recorded in the county recorder's office that states the subject parcel of land was lawfully created (unconditional), or if unlawfully created, which contains conditions which if satisfied by the owner shall legitimize the parcel (conditional). A certificate of compliance does not grant development rights. Development rights are only obtained when permits or grants of approval for development are issued.

3. Filing an Application. An application for the approval of a Certificate of Compliance or Conditional Certificate of Compliance shall be filed with the City Engineer and include the information required by the City 
Engineer, together with the processing fee specified by the City Fee Schedule.

4. Review. All applications for certificates of compliance shall be submitted to the City Engineering Division for initial review. With consultation from the City Surveyor and Planning Division, the City Engineer will determine if he is able to process the application within the provisions set forth in this chapter. The City Engineer is authorized to issue unconditional or conditional certificates of compliance only based upon the circumstances which are specifically authorized in this chapter.

5. Approval. Upon approval, a certificate of compliance or conditional certificate of compliance in a form approved by the City Attorney shall be recorded with the county recorder.

\section{7-17. Subdivision Design and Improvements}

1. Purpose. This Chapter establishes standards for the design and layout of subdivisions, and the design, construction or installation of public improvements within subdivisions. The purpose of these standards is to ensure, through careful site evaluation and design, the creation of new usable parcels that are consistent with the General Plan and any applicable Community Plan.

2. Applicability. Each subdivision shall provide the improvements required by this Chapter, and any additional improvements required by conditions of approval. The subdivider shall construct all on- and offsite improvements according to standards approved by the City Engineer. No Final or Parcel Map shall be approved until the subdivider either completes the required improvements, or enters into a subdivision improvement agreement with the City for the work.

\section{Standards}

a. Sidewalks, curbs, and gutters. The City may require improved sidewalks, curbs or gutters within the right of way directly adjacent to lots contained within the subdivision of the adjacent right of way is a collector or arterial street. Where curbing is not required, some other type of edge definition and stabilization shall be specified by the review authority.

b. Pedestrian walkways away from street frontages. The City may require dedicated and improved pedestrian walkways in locations away from street frontages where necessary, to provide safe and convenient pedestrian access to a public facility or to otherwise provide convenient connections between existing pedestrian routes. Where walkways are required, the City Engineer shall specify standards for their design and construction.

c. Bicycle paths. The subdivider shall provide bicycle paths within an approved subdivision in compliance with where a bicycle path has been planned for within the subdivision boundaries by the Transportation Element of the General Plan, The City of 
South Lake Tahoe Bicycle Master Plan or any applicable Community plan.

d. Pedestrian lighting. All proposed subdivisions shall provide street lighting facilities designed and constructed in compliance with the City's Improvement Standards and Specifications, where it is required by the City's Improvement Standards and Specifications provided that the review authority shall ensure that:

i) The illumination of streets shall be unobtrusive and the lowest intensity compatible with safety; and

ii) No lighting shall be allowed that results in illumination above the tree canopy.

e. The subdivider shall pay any street light maintenance and energy fee required by the City.

f. Landscaping. Landscaping shall be provided in compliance with SLTCC Chapter 5 . The review authority may also require a subdivider to provide landscape buffers at appropriate locations to create a visual screen and minimize adverse impacts.

g. Monuments. The subdivider shall install monuments in compliance with the requirements of the City Engineer, and Map Act Chapter 4, Article 9.

h. Fire hydrants. If required by the Fire Marshal, the subdivider shall install fire hydrants of sizes and at locations approved by the Fire Marshal.

i. Public utilities and utility easements. Each approved parcel shall be provided connections to public utilities, including electricity, gas, water, sewer, and telecommunications services, which shall be installed as part of the subdivision improvements as provided by this Section. 
i) All existing and proposed utility distribution facilities (including electric, telecommunications and cable television lines) installed in and for the purpose of supplying service to any subdivision shall be installed underground. Equipment appurtenant to underground facilities, including surface mounted transformers, pedestal mounted terminal boxes and meter cabinets, and concealed ducts, shall also be located underground, entirely within a building, or screened from off-site view.

ii) Location of installation. Underground utility lines may be installed within street rights-of-way or along a lot line, subject to appropriate easements being provided if necessary. When installed within street rights-of-way, their location and method of installation, insofar as it affects other improvements within the street right-of-way, shall be subject to the approval of the City Engineer.

j. Storm drainage. Storm water runoff from the subdivision shall be collected and conveyed by an approved storm drain system in compliance with Lahontan BMP requirements. The use of natural drainage techniques in subdivision design is encouraged.

k. Protection of off-site properties. The storm drain system shall provide for the protection of abutting and other off-site properties that would be adversely affected by any increase in runoff attributed to the development; off-site storm drain improvements may be required to satisfy this requirement.

I. Where condominium subdivision of new construction is proposed, including Hotel-Condominiums, the project design must provide at least one of the following:

i) Building entrances oriented towards a central common area;

ii) Children's play areas;

iii) Bicycle path connected to existing bicycle paths;

iv) Special design or programs to promote the use of transit by residents;

v) Passive solar design and incorporation of energy efficient devices;

vi) Public access to recreation areas;

vii) Live-Work unit design;

viii)Design to accommodate seniors or other special needs occupants;

ix) Alley-loaded parking;

$x)$ Deed restriction affordable or moderate income units. $\mathrm{m}$. Large Subdivision Design. In addition to the requirements above, subdivisions that include eight units or more shall include amenities such as tot lots, child care, computer centers, etc. 
n. Priority Application Processing. Subdivision projects that are designed for special needs groups such as seniors, or disable residents or are design to Leadership in Energy and Environmental Design (LEED) or other national or state-wide recognized certification for green building shall be given priority for subdivision review by City staff.

4. Improvement Plans. After the approval of a Tentative Map, the subdivider shall diligently proceed to complete any subdivision improvements necessary to fulfill the conditions of approval. Before the construction of any improvements, the subdivider shall submit plans to the City as follows:

a. Preparation and content. Improvement plans shall be prepared by a California registered civil engineer and comply with the City Engineering Standards.

b. Review and approval. Improvement plans shall be reviewed and approved by the City Engineer, within the time limits provided by Map Act Section 66456.2.

c. Effect of approval. The final approval of improvement plans shall generally be required before approval of a Building Permit, parcel map, or final map. The approval of improvement plans shall not bind the City to accept the improvements nor waive any defects in the improvements as installed.

5. Improvement Agreement and Security. A subdivider may file a Parcel or Final Map before completion of all the improvements and conditions of approval of the Tentative Map, only when the subdivider first obtains Council approval of a subdivision improvement agreement executed and submitted for Council review by the subdivider, and provides the City performance security as required by this Section. Improvement agreements and required security shall also comply with Chapter 5 of the Map Act.

a. Contents of improvement agreement. A subdivision improvement agreement shall be submitted in a form acceptable to the City and approved by the City Attorney, and shall include the following provisions:

i) Description of improvements. A description of all improvements to be competed by the subdivider, with reference to the approved subdivision improvement plans;

ii) Time limit for construction. The period within which all required improvements will be completed to the satisfaction of the City Engineer;

iii) Completion by City. Provide that if the subdivider fails to complete all required improvements within the specified time, the City may elect to complete the improvements and recover the full cost and expenses thereof from the 
subdivider or the surety, including any attorney and legal fees associated with enforcement of the agreement;

iv) Surety requirement. Require the subdivider to secure the agreement by furnishing security to insure full and faithful performance and to insure payment to laborers and material suppliers. The amount of surety shall be based on an engineer's cost estimate submitted by the subdivider and approved by the City Engineer. The total cost of improvements to be guaranteed shall be as provided in the approved engineer's cost estimate; and

v) Phased construction. Provisions for the construction of improvements in units, at the option of the subdivider.

b. Security required to guarantee improvements. A subdivision improvement agreement shall be secured by adequate surety in a form approved as to form and sufficiency by the City Attorney, as follows:

i) Type of security. Improvement security shall be in the amount set forth or authorized in Map Act Section 66499.3.

ii) If the security is other than a bond or bonds furnished by a duly authorized corporate surety, an additional amount shall be included as determined by the Council as necessary to cover the cost and reasonable attorney's fees, which may be incurred by the City in successfully enforcing the obligation secured.

iii) The security shall also secure the faithful performance of any changes or alterations in the work, to the extent that such changes or alterations do not exceed 10 percent of the original estimated cost of the improvement.

6. Acceptance of improvements. Before acceptance for maintenance or final approval by the Planning Commission of subdivision improvements, the City Engineer shall verify that the improvement work has been completed in substantial compliance with the approved plans and specifications.

\section{7-18. Dedications and Exactions}

1. Purpose. This Chapter establishes standards for subdivider dedications of land or payment of fees in lieu thereof, in conjunction with subdivision approval.

2. Applicability. All proposed subdivisions shall comply with the requirements of this Chapter for dedications, reservations, or the payment of fees. The requirements of this Chapter as they apply to a specific subdivision shall be described in conditions of approval adopted by the review authority for the Tentative Map.

3. Reservations of Land for Public Facilities. A reservation of land within a proposed subdivision for public use may be required only when the review authority determines that: 
a. The requirement is based on policies and standards of the General Plan or applicable Community Plan for the uses for which a reservation is required, and the required reservation is in compliance with those policies and standards;

b. This Section has been in effect for at least 30 days prior to the filing of the Tentative Map;

c. The reserved area is of such size and shape as to permit the balance of the property within which the reservation is located to develop in an orderly and efficient manner; and

d. The amount of land reserved will not make development of the remaining land held by the subdivider to be economically unfeasible.

4. Findings Required for Dedications and Exactions. The review authority may require any of the dedications or exactions described in this Chapter through conditions of approval of a proposed Tentative Map only after first making findings which:

a. Identify the purpose for the dedication or exaction; and

b. Demonstrate that there is a reasonable relationship between the need for the dedication or exaction and the characteristics and impacts of the subdivision from which the dedication or exaction is required. 